\title{
Heat Resistance of Landfill Vegetation
}

\author{
Vasyl Popovych¹, Kateryna Stepova', Oksana Telak², Jerzy Telak ${ }^{3}$ \\ 1 Department of Ecological Safety, Lviv State University of Life Safety, 35 Kleparivska Str., 79007, Lviv, Ukraine \\ 2 Faculty of Safety Engineering and Civil Protection, The Main School of Fire Service, 52/54 Słowackiego Str., \\ 01-629, Warsaw, Poland \\ 3 Academy of Sport Education, ul. Jagiellońska 88, 00-001 Warszawa, Poland \\ * Coresponding author's e-mail: oksana.telak@gmail.com
}

\begin{abstract}
The heat resistance of vegetation at landfills is worth investigating for the determination of the optimal species for the biological reclamation phase. Insufficiency of experimental data on comparative stability of the stems and roots make it difficult to draw definitive conclusions about the heat resistance of the organs of the plants. It should be noted that many scientific works are devoted to the thermal stability of cultivated and agricultural plants. The reason is that the temperature conditions should be taken into account when growing vegetables, fruits and mushrooms. However, the heat resistance of weeds, specifically in landfills, has not been investigated thoroughly enough. Increased substrate temperatures at the landfill site, which are caused by the burning of waste, alter the microclimate, cause the greenhouse effect, and contribute to the climate change. The aim of the work was to investigate the heat resistance of 5 most common plant species that have evolved in the landfills of the Western Ukrainian Forest-Steppe District (Ukraine). The plant specimens were collected at the Lviv, Rava-Ruska and Chervonograd landfills. The heat resistance of landfill vegetation was determined according to the Matskov method during 2015-2018. The following materials, reagents and equipment were used for the experiments: green leaves of 5 species of the investigated plants (weeds) - wormwood (Artemisia vulgaris), absinthium (Artemisia absinthium), city goosefoot (Chenopodium urbicum), common burdock (Arctium lappa), dooryard plantain (Plantago major); $0.2 \mathrm{~N}$ hydrochloric acid; heated bath, thermometers, pipettes, petri dishes, crystallizers, electric hot plate, marker. The experiments were conducted in triplicate. During the investigation of the heat resistance of the landfill vegetation, it was found that the most stable species are wormwoods (Artemisia) in all areas of the landfill, and the least heat-resistant is city goosefoot. The temperature of $70-80^{\circ} \mathrm{C}$ is detrimental to all of the tested plants. It was found that the lowest heat resistance is characteristic of the plants that develop at the foot of landfills.
\end{abstract}

Keywords: temperature, heat resistance, landfill, vegetation, greenhouse effect, climate change.

\section{INTRODUCTION}

One of the most dangerous effects arising from the landfills operation is the burning of household waste. In addition to the burning of garbage with different morphological composition, the vegetation appeared during the natural overgrowth (vegetative reclamation), is exposed to high temperature (Popovych et al., 2018). Under the influence of direct fire most plants in landfills are killed. Certain species of plants are able to resist the temperature effects on landfills, which is caused by their physiological heat resistance. The landfill vegetation makes an important contribution to the environmental quality improvement, which involves the vegetative reclamation and phytoremediation.

Increased substrate temperatures at the landfill site, which are caused by the burning of waste, alter the microclimate, cause the greenhouse effect, and contribute to climate change.

The heat resistance of plants is the ability to withstand the high temperature over a certain period of time. The temperature of $40-60^{\circ} \mathrm{C}$ is supposed to be too high for the vegetative organs of most of the plants (Musienko, 1995). The phenomena of vegetation resistance have also been observed by Stout et al. (Stout et al., 1997) in Yellowstone National Park, USA. They revealed a heat-resistant species of Dichanthelium 
lanuginosum that is capable of withstanding the rhizosphere temperature of $40-57^{\circ} \mathrm{C}$. It was found that in response to increased temperature, individual $D$. lanuginosum plants, either grown in the lab or collected in the field, expressed a low molecular weight protein that cross-reacted with heat shock protein antibodies (Stout et al., 1997). These temperature regimes have a direct impact on the climate change.

The high temperature causes the damage of the structure and functions of the cytoplasmic membranes, proteins, inhibits the movement of the cytoplasm, reduces the mitotic index etc. in order to find out the specificity of the plants adaptation to the high temperature, it is efficient to explore their photosynthetic apparatus. High temperature causes the damage to the integrity of the semipermeable membranes in the cells of the leaf mesophyll, which results in the diffusion of substances across the cell and beyond. Such a leaf immersed in a hydrochloric acid solution changes colour to brown as a result of chlorophyll pheophytinization (oxidation). The plants heat resistance can be determined by their pheophytization (Tretyakov et al., 1990).

The heat resistance of the vegetation at landfills is worth investigating for determination of the optimal species for the biological reclamation phase. Insufficiency of the experimental data on comparative stability of the stems and roots makes it difficult to draw definitive conclusions about the heat resistance of the organs of the plants. However, field observations suggest that the most heat-resistant organ in plants is the stem and especially its modified forms.

It should be noted that many scientific works are devoted to thermal stability of the cultivated and agricultural plants. The reason is that the temperature conditions should be taken into account when growing vegetables, fruits and mushrooms. Specifically, Zhang et al. (Zhang et al, 2005) found that the high temperature has a positive effect on grapes (Vitis vinifera cv. Jingxiu), because it increases its frost resistance (cross-adaptation). Uchida et al. (Uchida et al., 2002) showed that the pretreatment of rice seedlings (Oryza sativa L. cv. Nipponbare) with a low $\mathrm{H}_{2} \mathrm{O}_{2}$ or NO content caused the better preservation of the green leaf tissue, as well as the increase of their salinity and heat resistance.

For the investigation of heat resistance of reed (Phragmites communis Trin.) presented by Song et al. (Song et al., 2006), samples were taken from two different growing conditions (dune reed and swamp reed). It was found that NO can effectively protect both types of plants from the oxidative stress caused by heat, and NO can also be a signal when the enzymes activate for active oxygen purification during thermal stress and thus provide heat resistance to these plants.

The investigations of thermal stress for tomato plants (Lycopersicon esculentum) and watermelon plants (Citrullus lanatus) were presented by Rivero et al. (Rivero et al., 2001) It was found that the heat stress in tomato plants occurred at $35^{\circ} \mathrm{C}$, while the chilling stress occurred in watermelon plants at $15^{\circ} \mathrm{C}$. It was proven that the heat stress causes the accumulation of phenols in the plant, activating their biosynthesis and inhibiting their oxidation. This can be considered as an acclimation mechanism of the plant to resist the thermal stress (Rivero et al., 2001).

$\mathrm{Ma}$ (Ma, 2004) showed the beneficial effect of $\mathrm{Si}$ on plants under various abiotic and biotic stresses. Silicon has been found to have an attenuation effect on various abiotic impacts, including salinity stress, metal toxicity, drought stress, radiation damage, nutrient imbalance, high temperature, freezing etc. These beneficial effects are mainly caused by the high accumulation of silicon dioxide on the surface. Si increases the heat resistance of plants. Agarie et al. (Agarie et al., 1998) observed that the leakage of the electrolyte caused by high temperature $\left(42.5^{\circ} \mathrm{C}\right)$ is less pronounced in the leaves grown with Si than in those grown without $\mathrm{Si}$. These results suggest that $\mathrm{Si}$ may be involved in the thermal stability of lipids in cell membranes, although this mechanism has not been elucidated. Heat resistance of weeds, specifically in landfills, has not been investigated thoroughly enough.

The aim of the work was to investigate the heat resistance of 5 most common plant species that have evolved in the landfills of the Western Ukrainian Forest-Steppe District (Ukraine).

\section{MATERIALS AND METHODS}

Plants sampling locations. Collection of the plant specimens was carried out on the territory of the Lviv, Rava-Ruska and Chervonograd landfills located within the Western Ukrainian ForestSteppe District.

Morphological characteristics of the landfills. The Lviv municipal landfill is located $3 \mathrm{~km}$ 
far from the northern border of Lviv. The landfill has been in operation since 1957. About 55 million $\mathrm{m}^{3}$ of garbage have been accumulated at the landfill during its operation. By 1990, it contained not only household waste but also toxic industrial wastes. According to last estimates, their amount reaches 2 million tonnes. In addition to garbage, more than 200 thousand tonnes of acid tars - wastes of VAT Lviv Oil Refinery - have been accumulated in the landfill. The total area of reservoirs with tars is about 5 hectares; they have accumulated about 250 thousand $\mathrm{m}^{3}$ of refinery waste containing sulfuric acid and 60 thousand $\mathrm{m}^{3}$ of acid water. Since 1990, only industrial waste of 3rd and 4th substance hazard categories has been taken to the landfill. It has been approved by the State Administration of Ecology and Natural Resources in the Lviv region. The thickness of the debris layer in the southeastern part of the landfill reaches $50 \mathrm{~m}$, in the northwestern part it ranges from $1-3$ to $10 \mathrm{~m}$. The total landfill area is $33.6 \mathrm{ha}$ (Voloshyn, 2012; Haydin et al., 2013). The combustion processes on the side faces of the landfill do not stop, polluting the environment within 5 $\mathrm{km}$ with toxic vapours and incomplete combustion products, causing the greenhouse effect and climate change.

The Chervonograd landfill is located $3 \mathrm{~km}$ south of Chervonograd. The landfill is formed on the territory administratively owned by the VP Mezhirichanska mine of DP Lvivvuhillya, which belongs to the Lviv-Volyn coal basin. The landfill disposes of 236 thousand tonnes of municipal waste. At the landfill a waste sorting line was introduced, which provides for the collection of polymeric waste and plastics. To the south, the landfill is bounded by a dam of the ditch. A section of the Lviv-Chervonograd highway passes $400 \mathrm{~m}$ west of the landfill. The waste incineration processes are not observed. The filtrate is released from the south side directly to the soil. No special ditches and drainage systems for filtration were built.

The Rava-Ruska landfill is located within the Zhovkva administrative district of the Lviv region. The land plot, which was provided for the landfill by the district council, has a maintained sanitary protection zone and meets the requirements of the State Sanitary Rules for the Planning and Development of Settlements. Its area is 5 hectares, and the projected capacity of 200 thousand tons. The agricultural lands used by the citizens for producing the agricultural products are located on the north and west sides of the landfill. On the south and east sides, the landfill borders with a forest. In general, the landfill was formed at the site of a sand quarry which is still in use. The burning processes are observed locally. The filtrate is discharged from the north and west sides directly into the agricultural areas. No special ditches and drainage systems for filtration were built.

Natural environment and climatic characteristics of the region. The relief of the Western Ukrainian Forest-Steppe District is intersected by deep river valleys and ravines. The climate is temperate, continental, with moderately warm, sufficiently hot summers and warm winters. The average annual temperature is $7.3^{\circ} \mathrm{C}$. West winds dominate with speed up to $4 \mathrm{~m} / \mathrm{s}$. In the winter months, the winds velocity is $6-10 \mathrm{~m} / \mathrm{s}$; stronger winds are rare. Rainfall ranges from 600 to 700 $\mathrm{mm}$ per year. In some dry years, for example, in 1961 , rainfall decreased to $300-350 \mathrm{~mm}$, and in humid years, as in 1975, increased to $1000 \mathrm{~mm}$ (Hensyruk S.A. et al., 1981). The growing season lasts 210 days. If the daily average temperatures are above $10^{\circ} \mathrm{C}$, it reaches up to 154 days.

Materials, reagents, equipment. The heat resistance of the landfill vegetation was determined according to the Matskov method (Tretyakov et al., 1990) for the 2015-2018 period. The following materials, reagents and equipment were used for the experiments: green leaves of 5 species of the investigated plants (weeds) - wormwood ( $A r$ temisia vulgaris), absinthium (Artemisia absinthium), city goosefoot (Chenopodium urbicum), common burdock (Arctium lappa), dooryard plantain (Plantago major); $0.2 \mathrm{~N}$ hydrochloric acid; heated bath, thermometers, pipettes, petri dishes, crystallizers, electric hot plate, marker. The experiments were conducted in triplicate.

Stages of the experiment. The procedure of heat resistance studies:

- The heated bath was heated to $40^{\circ} \mathrm{C}$.

- 5 leaves of each plant species were immersed in a heated bath for 30 minutes.

- For the first sample one leaf of each plant species was taken away from the heating bath and cooled in a petri dish with cold water (Fig. 1).

- Then the temperature of the heated bath was increased to $50^{\circ} \mathrm{C}$ and in 10 minutes another series of leaves was pulled out and cooled it in a new petri dish with cold water.

- After that, the temperature of the heated bath was increased to $60^{\circ} \mathrm{C}$ and in 10 minutes. The third series of leaf samples was pulled out and cooled. 


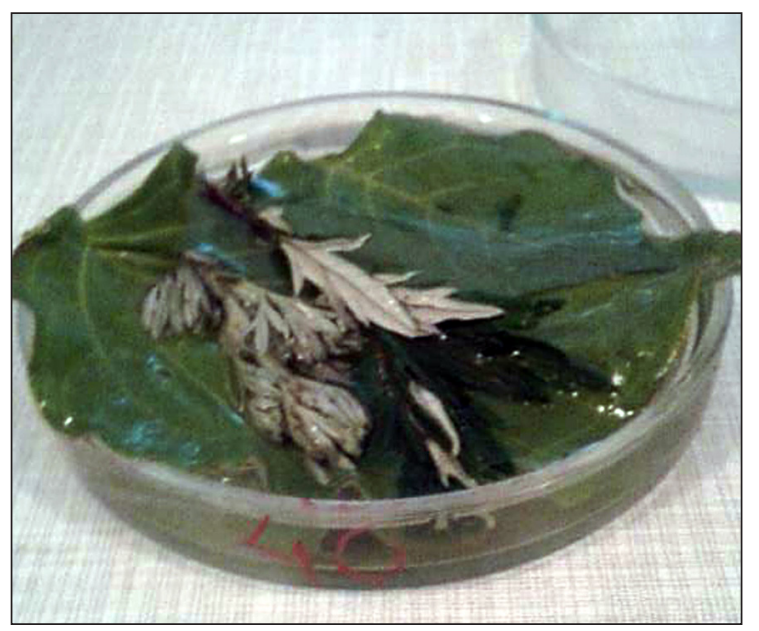

Fig. 1. Cooling of the leaves after removing them from the heated bath

- The same procedure was repeated for $70^{\circ} \mathrm{C}$ and $80^{\circ} \mathrm{C}$.

- The water in the petri dishes was replaced by $0.2 \mathrm{~N} \mathrm{HCl}$ solution and in $20 \mathrm{~min}$. the degree of leaves damage was estimated by the size of brown spots (Fig. 2).

\section{RESULTS AND DISCUSSION}

The investigated species (wormwood, absinthium, city goosefoot, common burdock, dooryard plantain) grow on the landfills in the areas with surface heterogeneity of substrate that is along roads and in places of runoff. Species do not compete. The placement of individuals in populations is spontaneous. It is found out that vegetation is better developed on the surface of landfills, on the north side (slight overgrowth) and at the foot. I order to compare the growth processes the samples of species were collected at a distance of $300 \mathrm{~m}$ from landfills.

The weed associations are better developed at the foot of the landfill on the shoreland of the filtration reservoirs. There is a species competition of wormwood, common burdock and dooryard plantain. The placement of individuals in populations is arranged in groups. The avant-garde species appear within a radius of $100 \mathrm{~m}$ or more from the foot of the landfill. Specific competition is increasing, including the tree and shrubbery vegetation. The projective cover of herbs is around $80-100 \%$.

As a result of the experiment, it was found that the heat resistance of the same plants in different sites of landfills differs. The explanation for this phenomenon is the impact of dangerous factors on their growth and development. Burning of waste, turbulence, solar radiation, products of waste burning, nutrient-depleted relief, increased radiation background, greenhouse effect have the greatest negative impact on the vegetation development. At the foot of the landfill, the vegetation is adversely affected by filtration effluents, evaporation of the filtrate, trampling due to the landfills operation, high content of heavy metals in the substrate. Within a radius of $300 \mathrm{~m}$ from the foot of the landfill, the impact of these hazardous factors is diminished.

Wormwood is supposed to be one of the most heat resistant species in landfills. However, this plant has different heat resistance in different areas. The plant exhibits the highest heat resistance at a distance of $300 \mathrm{~m}$ from the foot, and the lowest one at the foot of the landfill. For example, within a radius of $300 \mathrm{~m}$ from the foot at $70-80^{\circ} \mathrm{C}$, the degree of damage is $20 \%$. At the same temperatures at the

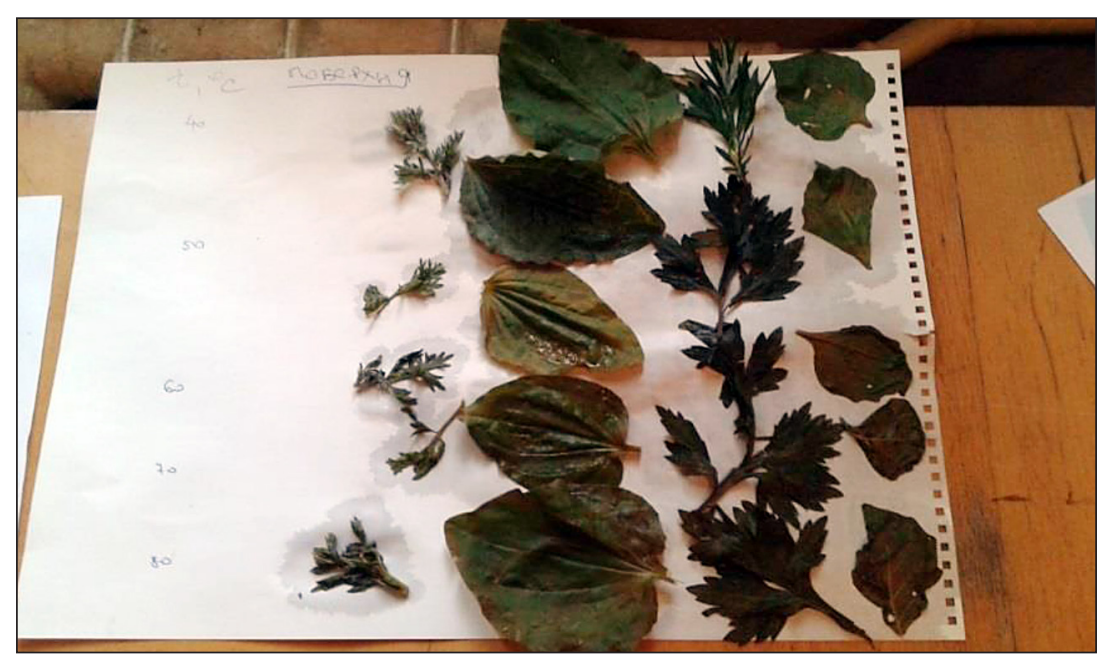

Fig. 2. Investigation of leaves damages 
foot of the landfill, the leaf damage is $40-50 \%$. On the landfill surface, the species is also characterized by a relatively high heat resistance (at 70$80^{\circ} \mathrm{C}$, the degree of damage is $20-40 \%$ ) (Fig. 3). The most unfavourable for the species exposed to the heat is the foot of the landfill.

Wormwood is the most heat-resistant at $300 \mathrm{~m}$ away from landfills (at $70-80^{\circ} \mathrm{C}$ the damage degree is $20 \%$ ). The lowest heat resistance is characteristic of the plants that grow at the foot (at $50-80^{\circ} \mathrm{C}$ the damage degree was $20 \%$ and more). On the surface of landfill the absinthium is heat resistant up to the temperature of $80^{\circ} \mathrm{C}$ (the damage degree reached 60\%) (Fig. 4). The most unfavourable area for absinthium is the foot of the landfill.

The least heat-resistant species in the landfills and surrounding area is city goosefoot. At a temperature of $40^{\circ} \mathrm{C}$, the damage to the species was $10-30 \%$ regardless of placement. At a temperature of $50^{\circ} \mathrm{C}$, the plants locates at the foot of the landfill was $100 \%$ affected by brown spots. In other landfill sites, $100 \%$ of the damage occurs at the temperature range of $70-80^{\circ} \mathrm{C}$ (Fig. 5).

The most unfavourable conditions for a dooryard plantain in regard to heat resistance are the surface and the foot of the landfill (at $70-80^{\circ} \mathrm{C}$ the damage is $100 \%$ for both sites). In a distance of $300 \mathrm{~m}$ from landfills, the damage of the species is more than $40 \%$ regardless of the affecting temperatures (Fig. 6).

The most unfavourable conditions for common burdock are also the surface and the foot of the landfill (at $70-80^{\circ} \mathrm{C}$ the damage is $100 \%$ for both sites). However, at a distance of $300 \mathrm{~m}$ from

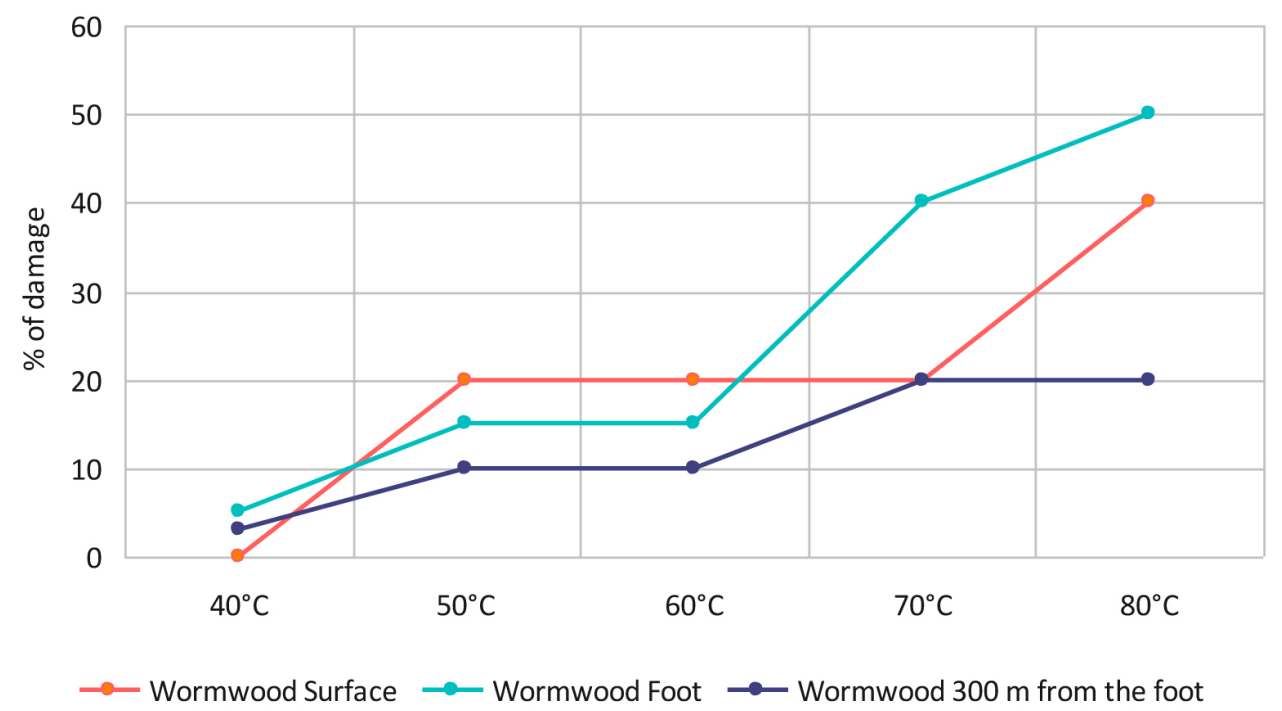

Fig. 3. The indicators of heat resistance of wormwood

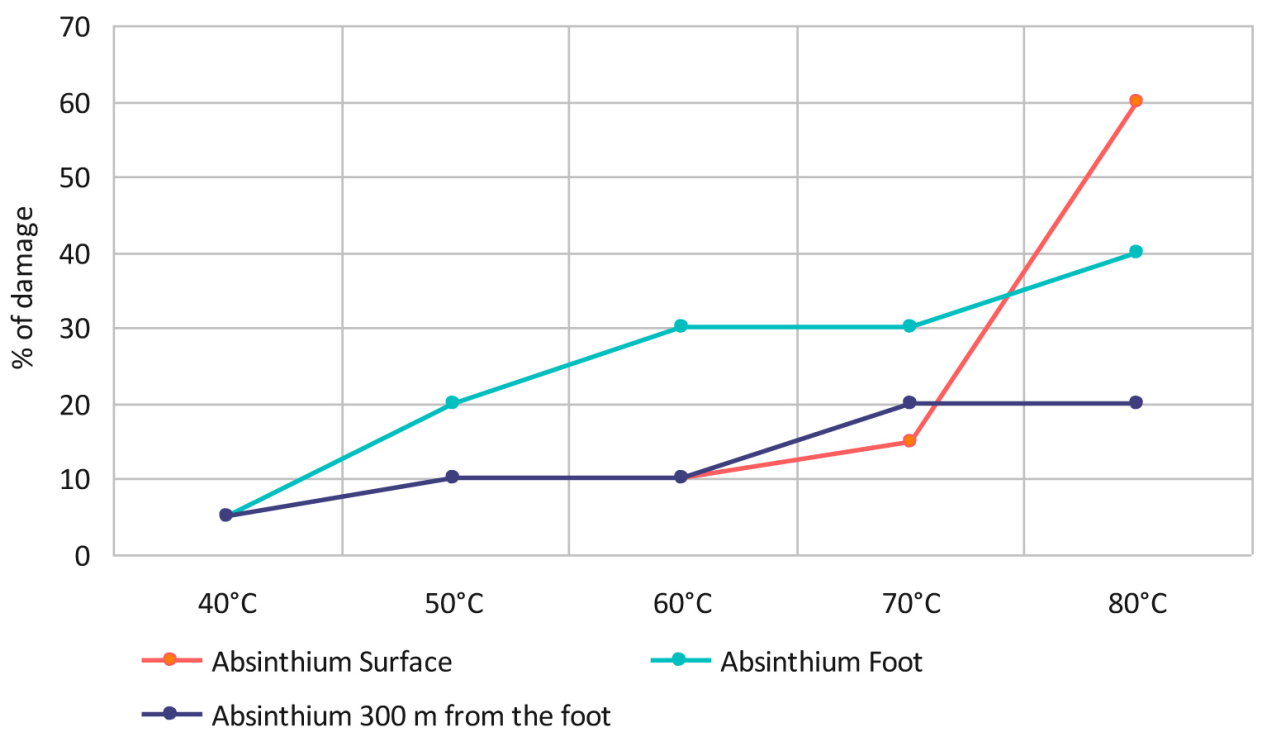

Fig. 4. The indicators of heat resistance of absinthium 


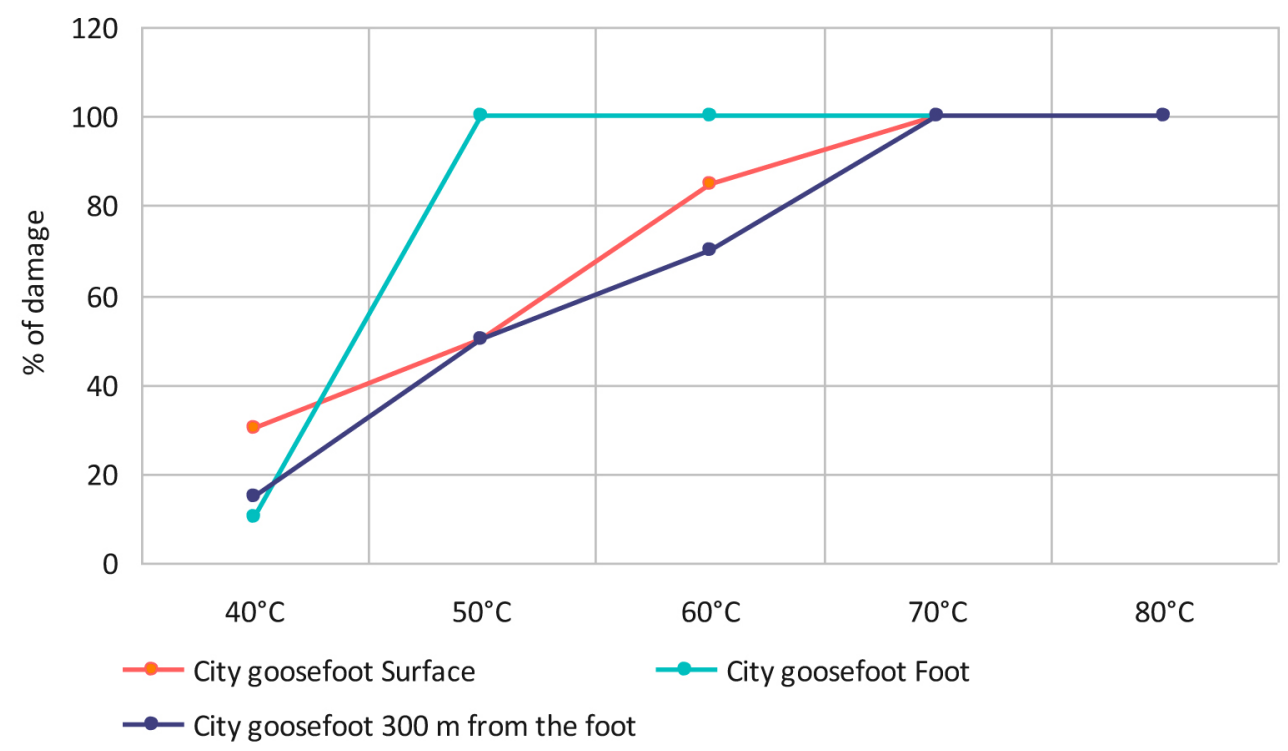

Fig. 5. The indicators of heat resistance of city goosefoot

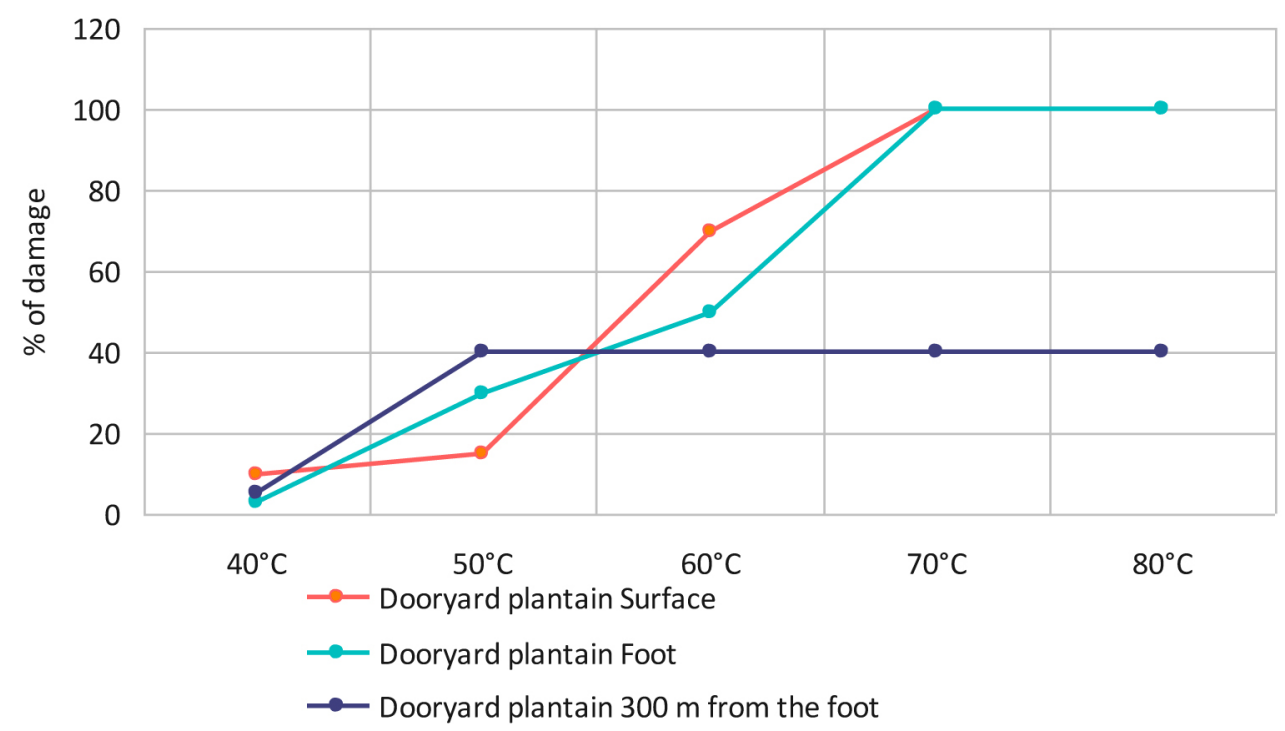

Fig. 6. The indicators of heat resistance of dooryard plantain

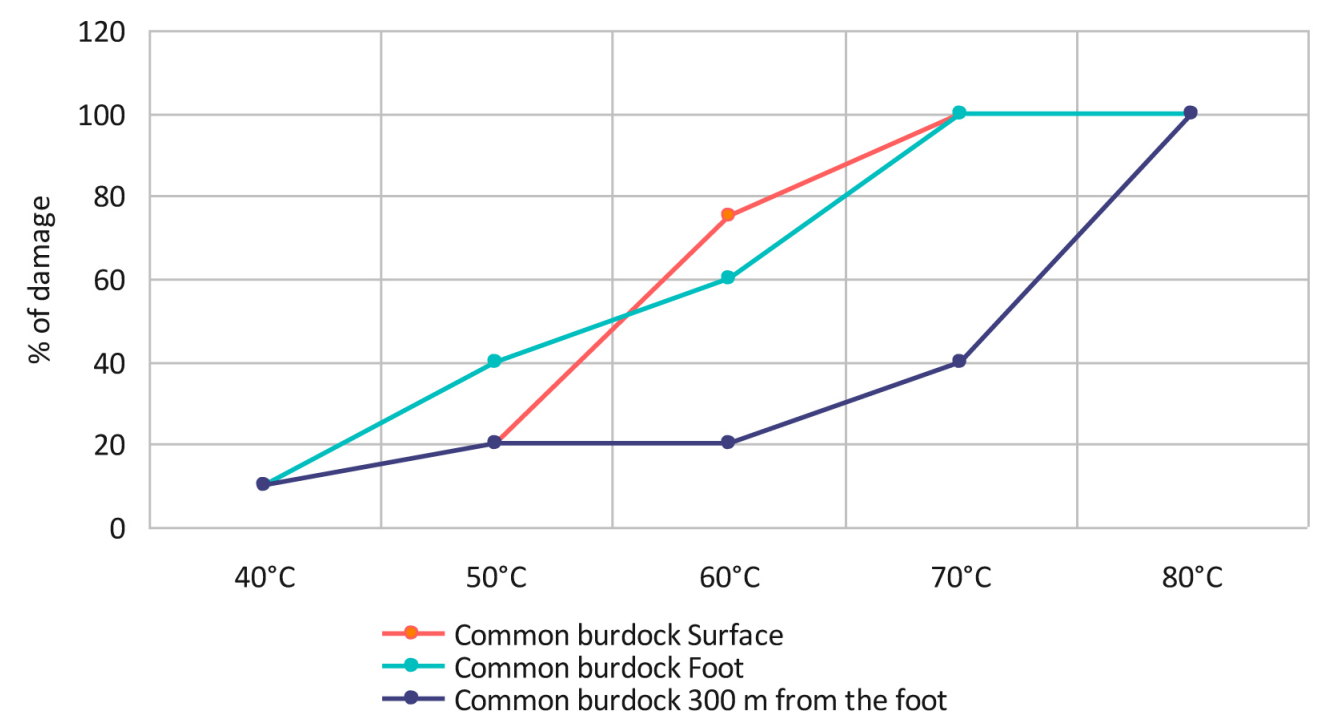

Fig. 7. The indicators of heat resistance of common burdock 
the foot, the species is resistant to temperatures of $40-60^{\circ} \mathrm{C}$ (20\% damage), but at a temperature of $80^{\circ} \mathrm{C}$ the damage is also $100 \%$ (Fig. 7).

\section{CONCLUSIONS}

The burning processes at the investigated landfills cause a change in the microclimate due to high temperatures and the greenhouse effect and as a result of the climate change in the region. The vegetation resulting from the phytomelioration processes on the landfill surface often dies due to high rhizosphere temperatures $\left(30-42^{\circ} \mathrm{C}\right)$. However, some species are able to withstand the high temperatures of the substrates, and also thrive, even in winter. Wormwood appeared to be one of the most heat resistant species in landfills. This plant exhibits high heat resistance in different areas. The plant shows the highest heat resistance at $300 \mathrm{~m}$ from the foot, and the lowest one at the foot of the landfills.

Absinthium is the most heat-resistant $300 \mathrm{~m}$ from landfills (at $70-80^{\circ} \mathrm{C}$ the damage is $20 \%$ ). On the surface of landfill this plant is heat-resistant, except for the temperature $80^{\circ} \mathrm{C}$, where the leaf damage was $60 \%$. The least heat-resistant species in the landfills and surrounding area is city goosefoot. At a temperature of $40^{\circ} \mathrm{C}$, the damage of the species was $10-30 \%$ regardless the location. At a temperature of $50^{\circ} \mathrm{C}$, the plant located at the foot of the landfill was affected by brown spots on $100 \%$. In other landfill sites, $100 \%$ of damage occurs in the temperature range of $70-80^{\circ} \mathrm{C}$. A temperature of $70-80^{\circ} \mathrm{C}$ is detrimental to all the investigated plants. In general, the lowest heat resistance is characteristic of the plants growing at the foot of the landfills.

\section{Acknowledgement}

The authors are grateful to the Head of the Department of Landscape Architecture, Landscaping and Urboecology of the Ukrainian National Forestry University (Lviv) Dr. Yaroslav Genik, and the professor of the same department Dr. Volodymyr Kucheryavy for the advising and their kind assistance in conducting the research.

\section{REFERENCES}

1. Agarie S., Hanaoka N., Ueno O., Miyazaki A., Kubota F., Agata W. and Kaufman P.B. 1998. Effect of silicon on tolerance to water deficit and heat stress in rice plants (Oryza sativa L.), monitored by electrolyte leakage. Plant Prod. Sci., 1, 96-103. Available at: https://doi.org/10.1626/pps.1.96

2. Haydin A.M. et al. 2013. Khimichnyi sklad filtrate Lvivskoho polihonu tverdyh pobutovykh vidkhodiv. Pryroda Zakhidnoho Polissya ta prylehlykh terytoriy. 10, 43-49 (in Ukrainian).

3. Hensyruk S.A. et al. 1981. Kompleksnoye lesokhozyaystvennoye rayonirovaniye Ukrainy i Moldavii (Integrated forestry zoning of Ukraine and Moldova)-Kiev: "Naukova dumka", 360 (in Russian).

4. Ma J. F. 2004. Role of silicon in enhancing the resistance of plants to biotic and abiotic stresses. Soil Science and Plant Nutrition, 50:1, 11-18. Available at: http://dx.doi.org/10.1080/00380768.2004.10408447

5. Musienko M.M. 1995. Phyziologiya rasteniy (Plant physiology) - Kiev:'Vyshaya shkola", 503 (in Russian).

6. Popovych V., Stepova K., Prydatko O. 2018. Environmental hazard of Novoyavorivsk municipal landfill. MATEC Web of Conferences 247, 00025. FESE 2018. Available at: https://doi.org/10.1051/ matecconf/201824700025

7. Rivero R. M., Ruiz J. M., Garcia P. C., Lopez-Lefebre L. R., Sanchez E., Romero L. 2001. Resistance to cold and heat stress: accumulation of phenolic compounds in tomato and watermelon plants. Plant Science. 160, 315-321. Available at: https://doi. org/10.1016/S0168-9452(00)00395-2

8. Song L., Ding W., Zhao M., Sun B., Zhang L. 2006. Nitric oxide protects against oxidative stress under heat stress in the calluses from two ecotypes of reed. Plant Science. 171, 449-458. Available at: https:// doi:10.1016/j.plantsci.2006.05.002

9. Stout R. G., Summers M. L., Kerstetter T., McDermott T. R. 1997. Heat- and acid-tolerance of a grass commonly found in geothermal areas within Yellowstone National Park. Plant Science. 171, 1-9.

10. Tretyakov N.N., Karnaukhova L.A. et al. 1990. Praktikum po phyziologii rasteniy (Plant physiology tutorial) - Moscow: "Agropromizdat", 271 (in Russian).

11. Uchida A., Jagendorf A. T., Hibino T., Takabe T., Takabe T. 2002. Effects of hydrogen peroxide and nitric oxide on both salt and heat stress tolerance in rice. Plant Science. 163, 515-523. Available at: https://doi.org/10.1016/S0168-9452(02)00159-0

12. Voloshyn P. 2012. Analiz vplyvu Lvivskoho smittyezvalyshcha na pryrodne seredovyshche. Visnyk Lvivskoho universytetu, 26, 139-147 (in Ukrainian).

13. Zhang J., Huang W., Pan Q., Liu Y. 2005. Improvement of chilling tolerance and accumulation of heat shock proteins in grape berries (Vitis vinifera cv. Jingxiu) by heat pretreatment. Postharvest Biology and Technology. 38, 80-90. Available at: https:// doi:10.1016/j.postharvbio.2005.05.008 